Jurnal Indobiosains. Vol. 2 No. 2. Edisi Agustus 2020

https://jurnal.univpgri-palembang.ac.id/index.php/biosains

\title{
RESPON PERTUMBUHAN TANAMAN SAWI CAISIM (Brassica juncea L.) TERHADAP PUPUK ORGANIK CAIR BUAH PEPAYA (Carica papaya L.)
}

\author{
Khusnul Khotimah ${ }^{1}$, Inka Dahlianah ${ }^{2}$, Dewi Novianti ${ }^{3}$ \\ ${ }^{1,2,3}$ Program Studi Biologi, Fakultas Matematika dan Ilmu Pengetahuan Alam \\ Universitas PGRI Palembang \\ *e-mail: khusnulkhotimah0897@gmail.com
}

\begin{abstract}
This research is about liquid organic fertilizer made from papaya (Carica papaya L.). The aim is to study the proper dosage of liquid fertilizer for caisim mustard (Brassica juncea L.) which is carried out in April to May 2020 in the yard in Surya Adi Village, Mesuji District, OKI Regency, South Sumatra Province. This research uses a completely randomized design method (CRD), namely the administration of liquid papaya fruit fertilizer consisting of 5 treatments and 5 replications, namely P0 (without liquid organic fertilizer, as a control), P1 (150ml liquid organic fertilizer), P2 (200ml organic fertilizer liquid), P3 (250ml liquid organic fertilizer), P4 (300ml liquid organic fertilizer). The results showed that the response of Caisim mustard growth to the application of liquid papaya organic fertilizer in P3 treatment $(250 \mathrm{ml}$ liquid organic fertilizer) produced the highest average value of $39.6 \mathrm{~cm}$, 15 leaves and 15.6 grams, while the lowest average value is the P0 treatment (without the provision of liquid organic fertilizer / control) that is equal to $34.5 \mathrm{~cm}$, the number of leaves is 10.6 strands, and the wet weight is $85.2 \mathrm{gr}$.
\end{abstract}

Keywords: Dosage, Mustard Caisim, Papaya Fruit Liquid Organic Fertilizer

\begin{abstract}
ABSTRAK
Penelitian ini tentang pupuk organik cair berbahan baku buah papaya (Carica papaya L.). Tujuan untuk mengkaji pemberian dosis pupuk cair yang tepat terhadap tanaman sawi caisim (Brassica juncea L.) yang dilakukan pada bulan April hingga Mei 2020 di lahan pekarangan di Desa Surya Adi, Kecamatan Mesuji, Kabupaten OKI, Provinsi Sumatera Selatan. Penelitian ini menggunakan metode rancangan acak lengkap (RAL) yaitu pemberian pupuk organik cair buah pepaya yang terdiri dari 5 perlakuan dan 5 ulangan yaitu $\mathrm{P}_{0}$ (tanpa pupuk organik cair, sebagai kontrol), $\mathrm{P}_{1}\left(150 \mathrm{ml}\right.$ pupuk organik cair), $\mathrm{P}_{2}$ (200ml pupuk organik cair), $\mathrm{P}_{3}$ (250ml pupuk organik cair), $\mathrm{P}_{4}(300 \mathrm{ml}$ pupuk organik cair). Hasil penelitian menunjukkan bahwa respons pertumbuhan tanaman sawi caisim terhadap pemberian pupuk organik cair buah pepaya pada perlakuan $\mathrm{P}_{3}(250 \mathrm{ml}$ pupuk organik cair) menghasilkan nilai rata-rata tertinggi sebesar 39,6 cm, jumlah daun 15 helai dan berat basah tanaman 144,6 gr, sedangkan nilai rata - rata terendah terdapat perlakuan $\mathrm{P}_{0}$ (tanpa pemberian pupuk organik cair/kontrol) yaitu sebesar $34,5 \mathrm{~cm}$, jumlah daun 10,6 helai, dan berat basah 85,2 gr.
\end{abstract}

Kata Kunci: Dosis, Sawi Caisim, Pupuk Organik Cair Buah Pepaya 


\section{PENDAHULUAN}

Tanaman sawi caisim (Brassica juncea L.) merupakan tanaman yang termasuk kedalam familia Brassicaceae yaitu masih satu famili dengan kubis, brocoli dan lobak yang mempunyai ciri khas empat kelopak bunga yang tersusun menyerupai tanda silang (Untara, 2014). Tanaman sawi mengandung banyak vitamin dan mineral. Kadar vitamin berupa K, A, C, E, folat, serta mengandung alkaloida, flavonoida, saponin, asam amino triptofan dan serat pangan. Sawi berhasiat sebagai obat nyeri pada tenggorokan, obat sakit kepala, obat batuk, anti hipertensi, peluruh air seni, mengobati penyakit jantung dan berbagai jenis kanker. Manfaat lainnya adalah menghindarkan ibu hamil dari anemia (Wijaya, 2010).

Menurut BPS (2018), di Sumatera Selatan produksi sawi pada tahun 2015, 2016, 2017 berturut-turut mengalami peningkatan yaitu: $3.246,3.278,3.780$ ton. Namun pada tahun 2018 mengalami penurunan yaitu menjadi 3.615 ton. Produksi sawi pengalami penurunan sebanyak 165 ton, beberapa faktor yang mempengaruhi penurunan hasil produksi sawi dapat terjadi karena salah satunya disebabkan oleh kurangnya pemupukan.

Salah satu upaya yang dapat dilakukan untuk meningkatkan produksi tanaman sawi yaitu dengan pemupukan. Mubarok (2019), menyatakan bahwa penerapan teknik penanaman yang kurang tepat dan kesuburan tanah yang terus menurun dapat menyebabkan produksi sawi menurun. Pemupukan dapat dilakukan secara organik dan anorganik. Menurut Sedayu (2014), pemupukan secara anorganik dalam jangka waktu yang panjang dapat menimbulkan dampak negatif bagi tanah pencemaran tanah dan air, serta penurunan tingkat kesuburan tanah, sedangkan pemupukan secara organik tidak menimbulkan dampak negatif bagi tanah. Menurut Baharudin et al. (2013), pupuk organik dapat memperbaiki sifat sifat biologis, kimia, dan fisik pada tanah, serta dapat menggemburkan kembali tanah pertanian. Lebih lanjut menurut Dahlianah (2019), Pemakaian pupuk anorganik yang relatif tinggi dan terus menerus menimbulkan dampak yang negatif, karena lahan akan mengalami penurunan (degradasi) sebagai akibat hilangnya bahan organik didalam tanah.

Pupuk organik terdiri dari dua jenis yaitu pupuk organik padat dan pupuk organik cair. Pupuk organik cair mengandung unsur hara makro dan mikro yang cukup tinggi dan aman terhadap lingkungan serta manusia (Taufika, 2011). Salah satu pupuk organik cair adalah pupuk organik cair dari buah pepaya yang sudah tidak layak dikonsumsi. Buah pepaya diolah menjadi pupuk organik cair untuk membantu memberi nutrisi bagi pertumbuhan tanaman. Pupuk organik cair berbahan baku buah pepaya mengandung karbohidrat, kalsium, kalium, magnesium, besi, dan fosfor yang tinggi, sehingga sangat baik untuk pertumbuhan serta perkembangan mikroorganisme dan tanaman (Nisa, 2016).

Pembuatan pupuk organik cair buah pepaya dapat dilakukan dengan menambahkan Effective Microorganism 4 (EM4), penambahan EM4 dapat mempercepat proses dekomposisi menjadi pupuk cair, dapat meningkatkan pertumbuhan serta dapat meningkatkan kualitas dan kuantitas produksi tanaman (Ardiningtyas, 2013).

Berdasarkan uraian diatas maka telah dilakukan penelitian dengan tujuan untuk menganalisis dosis yang tepat pada pupuk organik cair buah pepaya (Carica papaya L.) terhadap pertumbuhan tanaman sawi caisim (Brassica juncea L.). 


\section{BAHAN DAN METODE}

Penelitian ini menggunakan Rancangan Acak Lengkap (RAL) dengan satu faktor yaitu pemberian pupuk organik cair buah pepaya yang terdiri dari 5 perlakuan dan 5 ulangan :

$\mathrm{P}_{0}$ :Tanpa Pupuk Organik Cair

$\mathrm{P}_{1} \quad$ :Konsentrasi $15 \% \quad(150 \mathrm{ml}$ pupuk organik cair buah pepaya $+850 \mathrm{ml}$ air)

$\mathrm{P}_{2}$ :Konsentrasi $20 \% \quad(200 \mathrm{ml}$ pupuk organik cair buah pepaya $+800 \mathrm{ml}$ air)

$\mathrm{P}_{3}$ :Konsentrasi $25 \% \quad(250 \mathrm{ml}$ pupuk organik cair buah pepaya $+750 \mathrm{ml}$ air)
$\mathrm{P}_{4}$ :Konsentrasi $30 \% \quad$ (300ml pupuk organik cair buah pepaya $+700 \mathrm{ml}$ air)

Data dianalisis menggunakan analisis sidik ragam. Jika perlakuan berpengaruh nyata, maka dilanjutkan dengan uji lanjut BNT dengan membandingkan F-hitung dengan F-tabel pada taraf $\alpha 5 \%$.

\section{HASIL DAN PEMBAHASAN}

Hasil Analisis Sidik Ragam respons pemberian pupuk organik cair buah pepaya memberikan pengaruh nyata terhadap pertumbuhan tinggi tanaman sawi caisim, maka dilakukan uji Beda Nyata Terkecil (Tabel 1).

Tabel 1. Uji Beda Nyata Terkecil Respons Pertumbuhan Tinggi Tanaman Sawi Caisim (Brassica juncea L.) Terhadap Pupuk Organik Cair Buah Pepaya (Carica papaya)

\begin{tabular}{cc}
\hline Perlakuan & Rata - rata \\
\hline P0 & $\mathbf{3 4 , 5}$ a \\
P1 & $37,2 \quad \mathrm{~b}$ \\
P2 & $38,8 \quad \mathrm{c}$ \\
P3 & $\mathbf{3 9 , 6}$ d \\
P4 & $37 \quad \mathrm{~b}$ \\
\hline
\end{tabular}

\section{BNT 5\% = 1,01}

Keterangan : Rata - rata dalam tabel yang diikuti oleh huruf yang sama berbeda tidak nyata pada uji BNT 5\%

Berdasarkan Tabel 1 terlihat bahwa pemberian dosis pupuk organik cair buah pepaya mulai dari perlakuan $\mathrm{P}_{0}$ (tanpa pemberian pupuk organik cair/kontrol), perlakuan $\mathrm{P}_{1}(150 \mathrm{ml}$ pupuk organik cair $)$, perlakuan $\mathrm{P}_{2}(200 \mathrm{ml}$ pupuk organik cair) dan perlakuan $\mathrm{P}_{3}(250 \mathrm{ml}$ pupuk organik cair) mengalami peningkatan terhadap tinggi tanaman sawi caisim sebesar 39,6 cm. sedangkan pemberian pupuk dengan perlakuan $\mathrm{P}_{4}$ (300 ml pupuk organik cair) justru menyebabkan pertumbuhan tanaman sawi caisim mengalami penurunan pada tinggi tanaman sebesar $37 \mathrm{~cm}$. Meskipun secara statistik angka rata-rata pertumbuhan tinggi tanaman pada perlakuan $\mathrm{P}_{4}$ lebih besar daripada perlakuan $\mathrm{P}_{0}$. Sesuai dengan hasil penelitian Parintak (2018), menyatakan bahwa perlakuan $\mathrm{P}_{0}$ (kontrol), $\quad \mathrm{P}_{1}$ konsentrasi $10 \%, \quad \mathrm{P}_{2}$ konsentrasi $20 \%$ berturut turut mengalami peningkatan, sedangkan pemberian konsentrasi $30 \%$ pupuk organik cair limbah buah pepaya dan kulit nanas mengalami penurunan pada pertumbuhan tinggi batang tanaman kangkung darat.

Penurunan pertumbuhan tinggi tanaman sawi caisim pada perlakuan $\mathrm{P}_{4}$ diduga karena pada perlakuan $\mathrm{P}_{4}(300 \mathrm{ml}$ pupuk organik cair) pemberian dosis pupuk yang tidak seimbang atau melebihi dosis yang dibutuhkan oleh tanaman. 
Menurut Nissa (2016), menyatakan bahwa perlu adanya pemberian unsur hara yang tepat dan seimbang, karena kekurangan unsur hara atau kelebihan unsur hara dapat menyebabkan pertumbuhan yang tidak optimal pada tanaman. Menurut Indrawati et al. (2012), pemberian kadar fosfor yang berlebihan dapat menghambat pertumbuhan tanaman karena terjadi ikatan N-P yang menyulitkan tanaman menyerap unsur nitrogen, sedangkan kelebihan unsur kalsium mempengaruhi $\mathrm{pH}$ tanah sehingga tanaman menjadi kerdil, daun menguning, dan tanaman rendah.

Perlakuan $\mathrm{P}_{3}$ menunjukkan nilai rata-rata tertinggi yaitu $39,6 \mathrm{~cm}$, hal tersebut diduga kandungan unsur hara makro dan unsur hara mikro yang terdapat pada pupuk organik cair tersebut telah mencukupi sesuai dengan yang dibutuhkan oleh tanaman sawi caisim. Sesuai dengan pendapat Parintak (2018), tanaman yang tumbuh akan memberikan produksi yang optimal jika tersedia unsur hara yang mencukupi. Menurut Norhasanah (2011), menyatakan bahwa yang membantu pertumbuhan tinggi tanaman sawi caisim yaitu unsur kalsium sebanyak $23 \mathrm{mg}$ dan unsur fosfor $12 \mathrm{mg}$ yang terkandung pada buah pepaya.
Unsur kalsium berpengaruh terhadap pertumbuhan tanaman meninggi keatas, pembentukan kuncup dan diperlukan dalam pemanjangan sel dan pembelahan sel, sedangkan Unsur fosfor berperan dalam membantu perkembangan akar muda, tanaman membutuhkan akar yang subur agar dapat memperkuat berdirinya tanaman dan dapat meningkatkan penyerapan unsur hara. Keseluruhan unsur hara yang diserap tanaman saling mempengaruhi satu sama lain sehingga pupuk organik cair mendukung pertumbuhan tinggi tanaman, dan adanya pembelahan dan perpanjangan sel mengakibatkan meningkatnya tinggi tanaman (Haryadi et al., 2015). Sesuai dengan pendapat Dahlianah (2014), bahwa salah satu upaya peningkatan pertumbuhan tanaman adalah memenuhi kebutuhan hara yang mencukupi selama siklus hidup tanaman dengan pemupukan. Respons Pertumbuhan Jumlah Daun Tanaman Sawi Caisim (Brassica juncea L.) Terhadap Pupuk Organik Cair Buah Pepaya (Carica Papaya L.)

Hasil Analisis Sidik Ragam respons pemberian pupuk organik cair buah pepaya memberikan pengaruh nyata terhadap pertumbuhan jumlah daun tanaman sawi caisim, maka dilakukan uji Beda Nyata Terkecil (Tabel 2).

Tabel 2. Uji Beda Nyata Terkecil (BNT) Respons Pertumbuhan Jumlah Daun Tanaman Sawi Caisim (Brassica juncea L.) Terhadap Pupuk Organik Cair Buah Pepaya (Carica papaya L.)

\begin{tabular}{cc}
\hline Perlakuan & Rata - rata \\
\hline P0 & $\mathbf{1 0 , 6} \mathbf{a}$ \\
P1 & $12,6 \mathrm{~b}$ \\
P2 & $13,6 \mathrm{c}$ \\
P3 & $\mathbf{1 5} \mathbf{d}$ \\
P4 & $12,8 \mathrm{bc}$ \\
\hline
\end{tabular}

\section{BNT 5\% = 0,82}

Keterangan : Rata - rata dalam tabel yang diikuti oleh huruf yang sama berbeda tidak nyata pada uji BNT 5\%

Berdasarkan Tabel 2 terlihat bahwa pemberian dosis pupuk organik cair buah pepaya mulai dari perlakuan $\mathrm{P}_{0}$ (tanpa pemberian pupuk organik cair/ kontrol), 
perlakuan $\mathrm{P}_{1}(150 \mathrm{ml}$ pupuk organik cair $)$, perlakuan $\mathrm{P}_{2}(200 \mathrm{ml}$ pupuk organik cair) dan perlakuan $\mathrm{P}_{3}(250 \mathrm{ml}$ pupuk organik cair) mengalami peningkatan terhadap jumlah daun tanaman sawi caisim sebanyak 15 helai, sedangkan pemberian pupuk dengan perlakuan $\mathrm{P}_{4}$ (300 ml pupuk organik cair) justru menyebabkan pertumbuhan jumlah daun tanaman sawi caisim mengalami penurunan jumlah daun sebanyak 12,8 helai, meskipun secara statistik angka rata-rata pertumbuhan jumlah daun tanaman pada perlakuan $\mathrm{P}_{4}$ lebih besar daripada perlakuan $\mathrm{P}_{0}$ dan $\mathrm{P}_{1}$. Sesuai dengan hasil penelitian Parintak (2018), menyatakan bahwa pada perlakuan $\mathrm{P}_{0}$ (kontrol), $\quad \mathrm{P}_{1}$ konsentrasi $10 \%, \mathrm{P}_{2}$ konsentrasi $20 \%$ berturut turut mengalami peningkatan, sedangkan pemberian konsentrasi 30\% pupuk organik cair limbah buah pepaya dan kulit nanas mengalami penurunan pada pertumbuhan jumlah helai daun tanaman kangkung darat. Perlakuan dosis mulai dari $150 \mathrm{ml}$ hingga $250 \mathrm{ml}$ pupuk organik cair buah papaya diduga merupakan dosis yang sudah mampu memenuhi keadaan optimum kebutuhan unsur hara tanaman. Sedangkan dosis perlakuan $\mathrm{P}_{4}(300 \mathrm{ml}$ pupuk organik cair) diduga unsur hara yang diberikan melebihi jumlah yang seharusnya dibutuhkan oleh tanaman sawi caisim. Menurut pendapat Roidi (2016), menyatakan bahwa apabila unsur hara yang diberikan melebihi jumlah yang seharusnya dibutuhkan oleh tanaman, menyebabkan pertambahan jumlah daun tanaman tidak dapat berlangsung secara optimal. Kelebihan unsur hara nitrogen dapat menurunkan pH tanah, akan mengikat unsur hara lain sehingga akan sulit diserap tanaman dan menyebabkan keracunan pada tanaman.

Perlakuan $\mathrm{P}_{3} \quad(250 \mathrm{ml}$ pupuk organik cair) menunjukkan nilai rata rata pertumbuhan jumlah daun tanaman sawi caisim yang terbaik dengan rata rata 15 helai. Hal ini menunjukkan bahwa pada Perlakuan $\mathrm{P}_{3}$ (250ml pupuk organik cair) mengandung unsur hara nitrogen (N) dan unsur hara fosfor (P) sesuai dengan kebutuhan tanaman sawi caisim apabila dibandingan dengan perlakuan yang lainnya. Sependapat dengan pernyataan $\mathrm{f}$ airhurst et al. (2007) dalam Parintak (2018), menyatakan bahwa apabila nitrogen diberikan cukup pada tanaman, kebutuhan unsur hara lain seperti fosfor meningkat untuk mengimbangi laju pertumbuhan tanaman yang cepat. Unsur yang terdapat pada pupuk organik cair tidak berlebih maupun kekurangan sehingga pertumbuhan sawi caisim tumbuh dengan optimal. Terjadinya peningkatan pada jumlah daun tanaman sawi caisim juga dapat berhubungan dengan pertambahan tinggi tanaman. Apabila tanaman semakin tinggi, maka jumlah titik tumbuh daun semakin banyak, maka dari itu daun semakin banyak. Menurut Mufida (2013), bahwa unsur yang dapat merangsang pertumbuhan vegetatif (warna hijau) seperti daun yang sangat berguna dalam proses fotosintesis adalah nitrogen. Penyerapan hara nitrogen dapat meningkatkan pembentukan dan pertumbuhan daun pada tanaman. unsur nitrogen yang tersedianya dalam jumlah yang cukup pada tanaman akan melancarkan proses metabolisme pada tanaman dan memengaruhi pertumbuhan organ-organ pada tanaman seperti daun, batang dan akar. Ketersediaan nitrogen dan fosfor yang cukup didalam tanah akan diserap oleh akar tanaman sawi caisim dan dapat memberikan pertumbuhan jumlah daun yang optimal bagi tanaman tersebut. Menurut Liferdi (2009) dalam Parintak (2018), fosfor adalah hara makro esensial yang berperan penting dalam proses fotosintesis, asimilasi, dan respirasi. Fosfor merupakan komponen structural dari sejumlah senyawa molekul pentransfer energi ADP, ATP, NAD, NADH, serta senyawa sistem informasi genetik DNA. 
Hasil Analisis Sidik Ragam (ANSIRA) respons pemberian pupuk organik cair buah pepaya memberikan pengaruh nyata terhadap pertumbuhan berat basah tanaman sawi caisim. Karena berpengaruh nyata maka dilakukan uji Beda Nyata Terkecil (Tabel 3).

Tabel 3. Uji Beda Nyata Terkecil (BNT) Respons Pertumbuhan Berat Basah Tanaman Sawi Caisim (Brassica juncea L.) Terhadap Pupuk Organic Cair Buah Pepaya (Carica papaya L.)

\begin{tabular}{cc}
\hline Perlakuan & Rata - rata \\
\hline P0 & $\mathbf{8 5 , 2} \mathbf{a}$ \\
P1 & $104,4 \mathrm{~b}$ \\
P2 & $138,6 \mathrm{~d}$ \\
P3 & $\mathbf{1 4 4 , 6 ~ d}$ \\
P4 & $120 \mathrm{c}$ \\
\hline
\end{tabular}

BNT 5\% = 9,10

Keterangan : Rata - rata dalam tabel yang diikuti oleh huruf yang sama berbeda tidak nyata pada uji BNT 5\%

Berdasarkan Gambar 3 terlihat bahwa pemberian dosis pupuk organik cair buah pepaya mulai dari perlakuan $\mathrm{P}_{0}$ (tanpa pemberian pupuk organik cair/ kontrol), perlakuan $\mathrm{P}_{1}(150 \mathrm{ml}$ pupuk organik cair), perlakuan $\mathrm{P}_{2}(200 \mathrm{ml}$ pupuk organik cair) dan perlakuan $\mathrm{P}_{3}$ (250 ml pupuk organik cair) mengalami peningkatan terhadap berat basah tanaman sawi caisim sebesar 144,6gr, sedangkan pemberian pupuk dengan perlakuan $\mathrm{P}_{4}$ (300 ml pupuk organik cair) mengalami penurunan berat basah tanaman sawi caisim yaitu sebesar $120 \mathrm{gr}$. Meskipun secara statistik angka rata-rata pertumbuhan berat basah tanaman pada perlakuan $\mathrm{P}_{4}$ lebih besar daripada perlakuan $\mathrm{P}_{0}$ dan $\mathrm{P}_{1}$. Sesuai dengan hasil penelitian Parintak (2018), menyatakan bahwa pada perlakuan $\mathrm{P}_{0}$ (kontrol), $\mathrm{P}_{1}$ konsentrasi $10 \%$, berturut turut mengalami peningkatan, sedangkan pemberian $\mathrm{P}_{2}$ konsentrasi $20 \%$ dan konsentrasi $30 \%$ pupuk organik cair limbah buah pepaya dan kulit nanas mengalami penurunan pada pertumbuhan berat basah tanaman kangkung darat. perlakuan dosis pupuk mulai dari $150 \mathrm{ml}$ hingga $250 \mathrm{ml}$ pupuk organik cair buah papaya diduga merupakan dosis yang sudah mampu memenuhi keadaan optimum kebutuhan unsur hara tanaman. Sedangkan dosis $300 \mathrm{ml}$ pupuk organik cair buah papaya diduga merupakan dosis yang melebihi kebutuhan unsur hara tanaman. Hal ini menunjukkan bahwa berat basah tanaman dipengaruhi oleh kandungan air yang ada pada tanaman sawi caisim tersebut. Sesuai dengan pendapat Salisbury dan Ross (1995) dalam Parintak (2018), berat basah pada tanaman berhubungan dengan banyaknya air yang diserap dan setiap organ tanaman membutuhkan senyawa dalam jumlah besar, akan tetapi kandungan air dari suatu jaringan tanaman dapat berubah atau tidak stabil sesuai umur dan dipengaruhi oleh faktor lingkungan, apabila unsur - unsur fosfor, kalium atau suplai air tidak mencukupi, tanaman dapat menyerap nitrogen dalam jumlah yang berlebihan sehingga tanaman akan memberikan warna gelap, sekulen, dan tanaman mudah rusak.

Perlakuan $\mathrm{P}_{3}$ (250ml pupuk organik cair) menunjukkan nilai rata - rata pertumbuhan berat basah tanaman sawi caisim yang terbaik dengan rata - rata 
144,6 gr. Menurut Pramushinta dan Yulian (2020), menyatakan bahwa terdapat kandungan unsur hara nitrogen pada pupuk organik cair dimana nitrogen dapat meningkatkan perbandingan protoplasma terhadap dinding sel dan dapat mengakibatkan bertambah besar ukuran sel dengan dinding sel yang tipis, keadaan ini mengakibatkan daun banyak mengandung air. Menurut Mufida (2013), Air merupakan salah satu faktor yang menentukan proses pertumbuhan tanaman. Tanaman membutuhkan $\mathrm{CO}_{2}$ dari udara dan air dari tanah untuk membentuk gula dan karbohidrat dalam proses fotosintesis serta sebagai pelarut unsur hara sehingga unsur hara dapat diserap oleh akar tanaman.

\section{KESIMPULAN}

Berdasarkan hasil penelitian respons pertumbuhan tanaman sawi caisim (Brassica juncea L.) terhadap pemberian pupuk organik cair buah pepaya (Carica papaya L.) dapat disimpulkan bahwa pada perlakuan $\mathrm{P}_{3}$ (250 ml pupuk organik cair) menghasilkan nilai rata-rata tertinggi pada pertumbuhan tinggi tanaman yaitu $39,6 \mathrm{~cm}$, jumlah daun yaitu 15 helai dan berat basah tanaman yaitu 144,6 gr, sedangkan nilai rata - rata terendah yaitu perlakuan $\mathrm{P}_{0}$ (tanpa pemberian pupuk organik cair/kontrol) yang menghasilkan tinggi pertumbuhan tinggi tanaman yaitu $34,5 \mathrm{~cm}$, jumlah daun yaitu 10,6 helai, dan berat basah yaitu 85,2 gr.

\section{DAFTAR PUSTAKA}

Ardiningtyas, T.R. 2013. Pengaruh Penggunaan Effective Microorganism 4 (EM4) dan Molase Terhadap Kualitas Kompos dalam Pengomposan Sampah Organik. Skripsi. Universitas Negeri Semarang.
Badan Pusat Statistik Republik Indonesia. 2018. Statistik Tanaman Sayur dan Buah Semusim Indonesia 2018. Badan Pusat Statistik, Jakarta.

Baharudin, A., A. Suyanto, dan S. Sudaryanto. 2013. Pemanfaatan Limbah Pepaya (Carica papaya L.) dan Tomat (Solanum Iycopersicum L.) Untuk Mempercepat Pengomposan Sampah Organik. Jurnal Sanitasi 8(2):81-86.

Dahlianah, I. 2014. Pupuk Hijau Salah Satu Pupuk Organik Berbasis Ekologi dan Berkelanjutan. Jurnal Klorofil. Volume IX/Nomor 2 Desember 2014. ISSN 2085-9600.

Dahlianah, I. 2019. Respon Pertumbuhan dan Produksi Tanaman Sawi (Brassica juncea L.) Terhadap Pemberian Kompos Sampah Rumah Tangga. Jurnal Klorofil. Volume XIV-2:69-73 Desember 2019.ISSN 2443-3985

Hanafiah K.A., 2016. Rancangan Percobaan Teori dan Aplikasi. (Edisi ketiga). PT RajaGrafindo Persada. Jakarta.

Haryadi, H., H. Yetti., dan S. Yoseva. 2015. Pengaruh Pemberian Beberapa Jenis Pupuk Terhadap Pertumbuhan dan Produksi Tanaman Kailan (Brassica alboglabra L.). Jom Faperta. Vol 2 (2). 1-10 hlm

Indrawati R., Indradewa D. dan Utami S. N. H., 2012. Pengaruh Komposisi Media dan Kadar Nutrisi Hidroponik Terhadap Pertumbuhan dan Hasil Tomat (Lycopersicon esculentum). Skripsi. Universitas Udayana Bali. 
Mubarok, R.F.A., B. Tripama, dan B. Suroso. 2019. Efikasi Pupuk Organik Cair (POC) Buah Pepaya (Carica papaya L.) Terhadap Produktivitas Tanaman Mentimun (Cucumis sativus L.). Jurnal Agritrop 17(1):76-92

Mufida, L. 2013. Pengaruh Penggunaan Konsentrasi FPE (Fermented Plant Extrac) Kulit Pisang Terhadap Jumlah Daun. Kadar Klorofil dan Kadar Kalium Pada Tanaman Seledri (Apiumgraveolens). Semarang: IKIP PGRI Semarang. 126 hlm.

Nisa, K. 2016. Memproduksi Kompos dan Mikro Organisme Lokal (MOL). Jakarta: Bibit Publisher.

Norhasanah. 2011. Respons Pertumbuhan dan Hasil Tanaman Cabai Rawit (Capsicum frutescens L.) Varietas Cakra Hijau Terhadap Pemberian Abu Sekam Padi Pada Tanah Rawa Lebak. Jurnal Agroteknologi 1(1):1- 6

Pupuk Organik Cair dari Limbah Buah Pepaya dan Kulit Nanas Terhadap Pertumbuhan Kangkung Darat (Ipomea reptans Poir). Skripsi. Universitas Sanata Dharma Yogyakarta.
Pramushinta, I.A.K., dan R. Yulian. 2020. Pemberian POC (Pupuk Organik Cair) Air Limbah Tempe dan Limbah Buah Pepaya (Carica papaya L.) Terhadap Pertumbuhan dan Produktivitas Tanaman Pak Coy (Brassica Rapa L.). Journal of Pharmacy and Science 5(1).

Sedayu, B. 2014. Pupuk Cair Dari Rumput Laut Menggunakan Proses Pengomposan. Jurnal Pasca Panen Bioteknologi Kelautan dan Perikanan 9(1):61-68.

Taufika. 2011. Pengujian Beberapa Dosis Pupuk Organik Cair Terhadap Pertumbuhan dan Hasil Tanaman Wortel (Daucus Carota L.). Jurnal Tanaman Hortikultura.

Untara, Wahyu. 2014. Kamus Sains. Yogyakarta: Indonesia Tera.

Wijaya, K. 2010. Pengaruh Konsentrasi dan Frekuensi Pemberian Pupuk Organik Cair Hasil Perombakan Anaerob Limbah Makanan Terhadap Pertumbuhan Tanaman Sawi (Brassica juncea L.). Skripsi. Jurusan Biologi Fakultas Matematika dan Ilmu Pengetahuan Alam Universitas Sebelas Maret Surakarta. 